\title{
PROPERTIES OF WHITE BRAILLE PAPERS FOR LIBRARY OF CONGRESS PUBLICATIONS
}

\author{
By C. G. Weber
}

\section{ABSTRACT}

Representative papers used by commercial publishers of books for the blind were studied, and the relationship between quality of the raised dots forming the characters for reading by touch and paper characteristics was determined. The strength of the raised dots was found to be closely related to the tensile properties of the paper. The density of the paper is very important, because of its relation to the reading quality of the dots. Requirements of paper suitable for high-quality Braille publications are recommended.

\section{CONTENTS}

Page

I. Introduction

II. Description of Braille process printing 812

III. Description and properties of Braille papers studied

IV. Paper requirements for uniform, high quality-printing

\section{INTRODUCTION}

Braille papers were studied for the purpose of assisting the Library of Congress in the purchase of books for the blind. At the time the study was initiated, many types of papers were in use by Braille printers and current publications did not all have the quality of printing desired for Library of Congress publications. Since no accurate information on the relation of paper properties to quality of printing was available, the establishment of a quality standard required considerable study of the wide variety of papers in use, and correlation of paper characteristics with quality of printing. Books for the blind require paper with certain properties not essential in the case of papers for ink printing. In addition to sufficient strength to resist wear incidental to handling, this paper must permit the embossing of raised dots that are strong enough to resist deformation under the readers' fingers, and free from surface cracks or other harshness that might be irritating to the sensitive touch of the blind readers. 


\section{DESCRIPTION OF BRAILLE PROCESS PRINTING}

Braille process printing is a system of printing for the blind in which points or dots, raised above the surface of the paper, form characters which are read by touch. The processes of printing books and magazines for the blind in commercial Braille presses are generally classified under the two headings, wet printing and dry printing.

Dry printing, as the name implies, is done on the dry paper, and the resulting dots are generally considered unsuitable for books of permanent value. The use of this process is generally confined to magazines of a temporary nature. Since this class of publications is not purchased by the Library of Congress, papers for dry printing were not included in this study.

In wet-process Braille printing, the raised dots forming the characters are formed by embossing wet paper. The paper is prepared for printing by moistening it with water and allowing it to stand in covered piles until the moisture is uniformly distributed. After moistening, the paper is printed on platen presses using embossed plates, and subsequently dried in racks.

\section{DESCRIPTION AND PROPERTIES OF BRAILLE PAPERS STUDIED}

In order to obtain information on the relation of paper characteristics to the quality of the dots forming the printed characters, both printed and unprinted specimens of the papers used by a number of the leading Braille publishers were studied. The papers were somewhat comparable to commercial ledger papers in weight and quality. However, glue or starch surface sizing used extensively on ledger papers is not used on Braille papers because the surface sizing causes difficulty in wet process printing. The unprinted papers were tested for weight, thickness, bursting strength, folding endurance, tensile properties, ash, degree of sizing, and fiber composition by standard methods. ${ }^{1}$ The dots on printed specimens were tested for strength as indicated by resistance to crushing, and they were inspected for surface cracks and other imperfections. The resistance to crushing was determined by measuring, with a dial micrometer, the actual deformation caused by 100 gram deadweight loads on individual dots.

The data for the unprinted and printed papers are given in table 1.

1 Paper Testing Methods, Technical Association of the Pulp and Paper Industry, 122 E. 42d Street, New York, N.Y. 


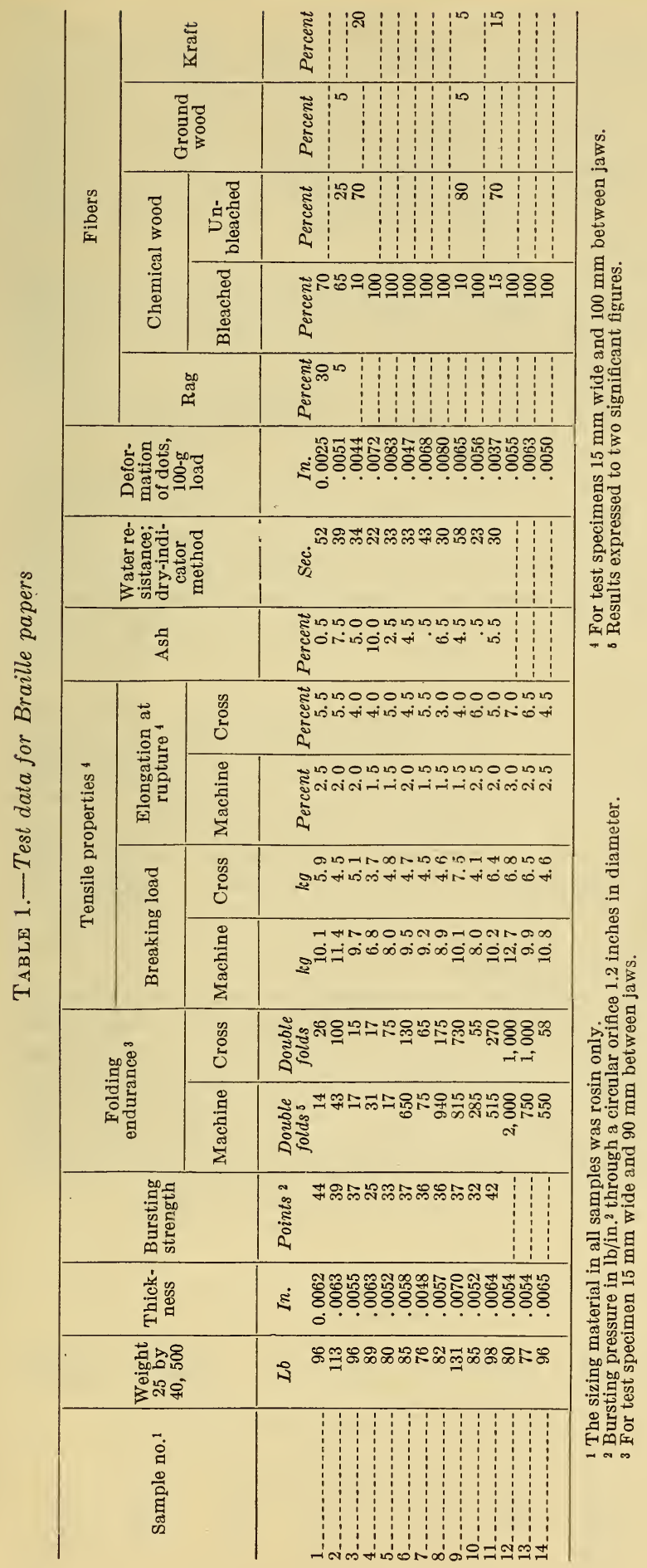


The tensile properties of the paper appeared to be the only strength properties closely related to the strength of the embossed dots. Papers of this type are characterized by a distinct grain, resulting in large directional differences in strength. The tensile breaking strength is much higher in the machine direction than in the cross direction, and the stretch, or elongation at rupture, is higher in the cross durection. The strength of the dots is obviously limited by the minimum values; hence by machine-direction elongation and cross-direction tensile breaking strength.

Elongation is apparently of first importance because dot formation requires considerable paper stretch, and failure to perform satisfactorily in this respect results in cracks which impair not only strength, but reading quality. Printing made up of dots that were deformed not more than 0.0050 inch under 100 -gram load withstood handling extremely well. Hence it appears essential to require tensile properties high enough to ensure dot deformation of not over 0.0050 inch. From the data in table 1 , it will be observed that this desired dot strength was not obtained in papers having cross direction tensile breaking strength of less than $4.5 \mathrm{~kg}$ or macnine direction elongation of less than 2.0 percent, hence these appeared to be minimum requirements. Machine direction tensile breaking strength and cross direction elongation are important with respect to handling and binding requirements, and minimum values of $9.0 \mathrm{~kg}$ and 4.0 percent respectively were considered desirable.

Inasmuch as a thickness of 0.0060 inch is regarded by commercial printers as most satisfactory for the average Braille press, that thickness was selected as standard. Of the papers that conformed closely to that thickness, those weighing approximately 85 pounds per ream ( 25 by 40 inches, 500 sheets) apparently had the best dots. Lower weights resulted in dots with poor strength, and higher weights were associated with dots with harsh and broken surfaces. Apparently the density of the paper, that is, the ratio of weight to thickness is important, and weight and thickness must both be closely controlled for satisfactory results in printing.

The validity of these findings was checked by testing additional papers. For this purpose, four papers with like fiber composition and comparable tensile properties, but varying somewhat with respect to ratio of weight to thickness, were selected and studied. These papers were tested for weight, thickness, and tensile properties. Printed specimens were tested for strength of dots, and rated with respect to reading quality of printing by blind readers at the Library of Congress. The results of these tests are given in table 2 .

TABLE 2

\begin{tabular}{|c|c|c|c|c|c|c|c|c|}
\hline \multirow{3}{*}{ Sample no. } & \multirow{3}{*}{$\begin{array}{l}\text { Weight } \\
25 \text { by } \\
40,500\end{array}$} & \multirow{3}{*}{$\begin{array}{l}\text { Thick- } \\
\text { ness }\end{array}$} & \multicolumn{4}{|c|}{ Tensile properties } & \multirow{3}{*}{$\begin{array}{l}\text { Deforma- } \\
\text { tion of dots } \\
\text { under 100- } \\
\text { gram load }\end{array}$} & \multirow{3}{*}{$\begin{array}{l}\text { Rating by } \\
\text { blind } \\
\text { readers }\end{array}$} \\
\hline & & & \multicolumn{2}{|c|}{ Breaking load } & \multicolumn{2}{|c|}{ Elongation } & & \\
\hline & & & Machine & Cross & Machine & Cross & & \\
\hline $\begin{array}{l}3 \mathrm{~A} \\
4 \mathrm{~A}\end{array}$ & $\begin{array}{r}L b . \\
85 \\
90 \\
78 \\
85 \\
8\end{array}$ & $\begin{array}{c}I n . \\
0.0057 \\
.0052 \\
.0054 \\
.0058 \\
.0\end{array}$ & \begin{tabular}{r|}
$k g$ \\
11.3 \\
11.4 \\
10.3 \\
9.5
\end{tabular} & $\begin{array}{l}k g \\
4.9 \\
5.7 \\
6.6 \\
4.7\end{array}$ & $\begin{array}{r}\text { Percent } \\
2.5 \\
2.0 \\
2.1 \\
2.0\end{array}$ & $\begin{array}{r}\text { Percent } \\
5.0 \\
6.0 \\
5.6 \\
4.5\end{array}$ & $\begin{array}{l}\text { In. } \\
0.0043 \\
.0058 \\
.0044 \\
.0047\end{array}$ & $\begin{array}{l}\text { Good. } \\
\text { Poor. } \\
\text { Do. } \\
\text { Preferred. }\end{array}$ \\
\hline
\end{tabular}


These results emphasize the importance of the proper weightthickness relationship. All of the papers had satisfactory strength and dots of high resistance to crushing; however, only two of the papers, $4 \mathrm{~A}$ and $1 \mathrm{~A}$, had dots satisfactory from a standpoint of reading quality. These two papers conformed to within a reasonable tolerance of the standard thickness of 0.0060 inch, and each weighed 85 pounds per ream. The other two papers differed somewhat from $4 \mathrm{~A}$ and $1 \mathrm{~A}$ as regards weight and thickness, and the dots of printed specimens had inferior reading surfaces. With these results in addition to the data given in table 1 as a basis, requirements for a white Braille paper suitable for use in the high-quality books for the blind desired by the Library of Congress were recommended.

\section{REQUIREMENTS FOR UNIFORM, HIGH-QUALITY PRINTING}

The paper required for wet process Braille printing for use in publications for the Library of Congress resembles a sulphite ledger, machine finish without surface sizing. From a consideration of all of the results, it appears that a paper of that type, having the properties shown in table 3, will be suitable for durable Braille publications of high quality.

TABLE 3

\begin{tabular}{|c|c|c|c|c|c|c|c|}
\hline \multirow{2}{*}{$\begin{array}{l}\text { Weight } \\
25 \text { by } \\
40,500\end{array}$} & \multirow{2}{*}{$\begin{array}{l}\text { Thick- } \\
\text { ness }\end{array}$} & \multicolumn{2}{|c|}{$\begin{array}{l}\text { Tensile breaking } \\
\text { strength (mini- } \\
\text { mum) }\end{array}$} & \multicolumn{2}{|c|}{$\begin{array}{l}\text { Elongation at } \\
\text { rupture (mini- } \\
\text { mum) }\end{array}$} & \multirow{2}{*}{ Stock } & \multirow{2}{*}{ Color } \\
\hline & & Machine & Cross & Machine & Cross & & \\
\hline $\begin{array}{c}L b . \\
85 \pm 4\end{array}$ & $\begin{array}{c}\text { In. } \\
0.0060 \\
\pm .0005\end{array}$ & ${ }^{k g} .0$ & $\stackrel{k g}{4.5}$ & $\begin{array}{r}\text { Percent } \\
2.0\end{array}$ & $\begin{array}{c}\text { Percent } \\
4.0\end{array}$ & $\begin{array}{l}\text { Free irom ground wood or unbleached } \\
\text { wood fibers. }\end{array}$ & White. \\
\hline
\end{tabular}

Three of the papers tested met the requirements (see table 3 ) in all respects, no. 6 in table 1 and nos. $1 \mathrm{~A}$ and $4 \mathrm{~A}$ in table 2 . All of those papers were entirely satisfactory as judged by blind readers. Also, paper conforming to the above requirements has been obtained in commercial quantities by a publishing house for use in the publications for the Library of Congress. This paper moistened and printed well, and the quality of dots printed on different presses by different publishers was in all cases entirely satisfactory to blind readers.

Washington, March 14, 1934. 